\title{
Virulence gene profiling of porcine Pasteurella multocida isolates of Assam
}

\author{
L. Babita Devi1 ${ }^{1,2}$, Durlav Prasad Bora², S. K. Das², R. K. Sharma2 ${ }^{2}$ S. Mukherjee ${ }^{3}$ and R. A. Hazarika ${ }^{4}$
}

1. KVK Churachandpur, ICAR Manipur Centre, Imphal, Manipur, India; 2. Department of Microbiology, College of Veterinary Science, AAU, Khanapara, Guwahati - 781 022, Assam, India; 3. Department of Veterinary Epidemiology and Preventive Medicine, CVSc, CAU, Aizawl, Mizoram, India; 4. Department of Veterinary Public Health, College of Veterinary Science, AAU, Khanapara, Guwahati - 781 022, Assam, India.

Corresponding author: Durlav Prasad Bora, e-mail: drdpbora@gmail.com

Co-authors: LBD: drbabitalais@rediffmail.com, SKD: drskdas53@gmail.com, RKS: dr.sharmark@rediffmail.com, SM: shyamananda1@gmail.com, RAH: rah1962@rediffmail.com

Received: 16-08-2017, Accepted: 19-02-2018, Published online: 21-03-2018

doi: 10.14202/vetworld.2018.348-354 How to cite this article: Devi LB, Bora DP, Das SK, Sharma RK, Mukherjee S, Hazarika RA (2018) Virulence gene profiling of porcine Pasteurella multocida isolates of Assam, Veterinary World, 11(3): 348-354.

\begin{abstract}
Aim: The present study was conducted to detect and identify the virulence genes in Pasteurella multocida isolates of porcine origin from Assam.

Materials and Methods: A total of 21 porcine $P$. multocida isolates were subjected to capsular typing and detection of virulence-associated genes ( $p f h A$, tbp $A, h g b B$, toxA, oma87, ompH, and $n a n B$ ) using various polymerase chain reaction (PCR) methods reported elsewhere. Further, pathogenicity of the porcine isolates of $P$. multocida was studied in mice. For each strain of $P$. multocida selected for pathogenicity trial, the group of mice was injected intraperitoneally (i/p) with $0.1 \mathrm{ml}$ of the inoculum prepared from respective field isolates, containing $10^{9}$ organisms per $\mathrm{ml}$.
\end{abstract}

Results: Capsular typing of the isolates by multiplex PCR showed two capsular types, type A (66.66\%) and type D (33.33\%). All the isolates were positive for outer membrane protein genes, oma 87 and $\mathrm{ompH}$ genes. Iron acquisition genes, $t b p A$ and $h g b B$, were detected in $14.28 \%$ and $19.04 \%$ of the isolates. The dermonecrotoxin encoding gene, tox $A$, was present in $23.80 \%$ of the isolates. Filamentous hemagglutinin encoding gene, $p f h A$, was detected in $28.57 \%$. The virulence gene distribution pattern of the isolates indicates the important role of the genes in disease pathogenesis.

Conclusion: From the present study, it can be concluded that tox $A$ gene is an important marker gene for defining the pathogenic potential of $P$. multocida strains in swine.

Keywords: capsular type, Pasteurella multocida, porcine, virulence-associated genes.

\section{Introduction}

Pasteurella multocida belonging to family Pasteurellaceae is a ubiquitous organism affecting multiple host species, thus causing several diseases such as hemorrhagic septicemia in cattle and buffalo, enzootic bronchopneumonia in cattle, sheep, and goats, atrophic rhinitis in swine, fowl cholera in poultry, and snuffles in rabbits $[1,2]$. It is one of the most fascinating Gramnegative, opportunistic animals and human pathogens with worldwide distribution.

The organism is grouped into 5 capsular serogroups (A, B, D, E, and F) with host specificity and disease induction [3]. Both toxigenic and non-toxigenic strains of serogroups A and D are associated with diseases in swine [4]. The pathogenicity of $P$. multocida is associated with various virulence factors which include diverse adhesions, dermonecrotic toxin, iron acquisition

Copyright: Devi, et al. Open Access. This article is distributed under the terms of the Creative Commons Attribution 4.0 International License (http://creativecommons.org/licenses/by/4.0/), which permits unrestricted use, distribution, and reproduction in any medium, provided you give appropriate credit to the original author(s) and the source, provide a link to the Creative Commons license, and indicate if changes were made. The Creative Commons Public Domain Dedication waiver (http://creativecommons.org/ publicdomain/zero/1.0/) applies to the data made available in this article, unless otherwise stated. proteins, sialidases, and outer membrane proteins [3,5-7]. These virulence factors help in colonization and invasion of the host, avoid host defense mechanisms, injury to host tissues, and stimulate host inflammatory response. The association of virulence factors with specific serogroups of $P$. multocida and its disease status in animals was also reported by Ewers et al. [8]. Since the pathogenic behavior of $P$. multocida could be predicted both by the virulence factors and the serogroups, evaluation of these virulence factors is important.

The present study investigates the distribution pattern of virulence-associated genes (VGAs) in P. multocida isolates of porcine origin.

\section{Materials and Methods}

\section{Ethical approval}

Ethical approval for the study was obtained from IAEC, Assam Agricultural University (AAU), Khanapara campus vide approval No. 770/ac/CPCSEA/ FVSc/AAU/IAEC/10-11/79 dated 09.09.2011.

\section{Source of $\boldsymbol{P}$. multocida isolates}

Twenty-one $P$. multocida isolates maintained in the ICAR Network Project on Hemorrhagic Septicemia, Department of Microbiology, College of Veterinary Science, Assam Agricultural University, 
Khanapara, Guwahati, were used for the study. The reference strain $\left(\mathrm{P}_{52}\right)$ was obtained from the Division of Bacteriology and Mycology, ICAR-Indian Veterinary Research Institute, Izatnagar, Bareilly, Uttar Pradesh.

\section{Revival and confirmation of $\boldsymbol{P}$. multocida isolates}

The isolates were reconfirmed by following standard bacteriological techniques and by $P$. multocida species-specific polymerase chain reaction (PM-PCR) as per the method described by Townsend et al. [9] using specific primer pairs (Table-1) [7,9-13]. PCR was done in $25 \mu \mathrm{l}$ reaction mixture by mixing $3.0 \mu \mathrm{l}$ DNA template with $12.5 \mu \mathrm{l}$ master mix (2X, Qiagen, Germany) and forward and reverse primers (10 pmol each). The PCR amplification was performed in a thermocycler (Applied Biosystems, USA) using the thermal conditions as initial denaturation at $94^{\circ} \mathrm{C}$ for $4 \mathrm{~min}, 35$ cycles of $94^{\circ} \mathrm{C}$ for $45 \mathrm{~s}, 55^{\circ} \mathrm{C}$ for $45 \mathrm{~s}, 72^{\circ} \mathrm{C}$ for $45 \mathrm{~s}$, followed by final extension at $72^{\circ} \mathrm{C}$ for $6 \mathrm{~min}$.

\section{Capsular typing}

Capsular PCR typing for all the isolates was done using a multiplex PCR as per the method described by Townsend et al. [10] with the reaction condition as illustrated in Table-2 [7,11].

\section{Virulence gene detection}

$P$. multocida isolates were tested for the presence of various VGAs, for example, $p f h A$, tbpA, hgbB, toxA, oma 87, ompH, and nanB by simplex PCR as per the method of Ewers et al. [8], using specific primers (Table-1) with the standard thermal conditions (Table-2). The amplified products were electrophoresed in $1.5 \%$ agarose gel in $1 \mathrm{X}$ tris acetate EDTA buffer at $60 \mathrm{~V}$ for $1 \mathrm{~h}$ with ethidium bromide stain and visualized with ultraviolet light by Gel Documentation System (Kodak, Biostep, Germany).

\section{Pathogenicity study of $\boldsymbol{P}$. multocida isolates}

Pathogenicity of the porcine isolates of $P$. multocida was studied in mice following the method described by Curtis [14] with slight modification. For each strain of $P$. multocida selected for pathogenicity trial, the group of mice was injected intraperitoneally (i/p) with $0.1 \mathrm{ml}$ of the inoculum prepared from respective field isolates, containing $10^{9}$ organisms per $\mathrm{ml}$ [15].

\section{Results}

All the bacterial isolates were revived in blood agar. The small, smooth, circular, glistening, and dewdrop-like colonies with a very characteristic odor and non-hemolytic colonies on blood agar plate (data not shown) were found to be Gram-negative coccobacilli and identified as P. multocida. The organisms were further confirmed based on specific amplification of KMT1 gene by PCR yielding an expected product size of $460 \mathrm{bp}$ (Figure-1) which was detected in all the isolates.

On capsular PCR typing, of 21 P. multocida isolates, serogroup D-specific gene (657 bp, Figure-2) was detected in seven $(33.33 \%)$ isolates, while serogroup A-specific gene (1044 bp, Figure-2) was detected in $14(66.66 \%)$ isolates. The reference strain gave an amplified product of $760 \mathrm{bp}$ band size corresponding to capsular type B.

On virulence gene detection PCR (Table-3), it was observed that the outer membrane genes (oma87 and $\mathrm{ompH}$ ) were found to be present in all the 21 isolates of porcine origin used in the present study and the reference strain giving expected band size of 838

Table-1: Sequences of the oligonucleotides used in the $P$. multocida multiplex capsular and virulence-associated genes typing assay of $P$. multocida.

\begin{tabular}{|c|c|c|c|c|}
\hline Gene & Primer & Sequence $\left(5^{\prime}-3^{\prime}\right)$ & Amplicon size & References \\
\hline KMT1 & $\begin{array}{l}\text { KMT1T7 Fwd } \\
\text { KMT1SP6 Rev }\end{array}$ & $\begin{array}{l}\text { ATCCGCTATTTACCCAGTGG } \\
\text { GCTGTAAACGAACTCGCCAC }\end{array}$ & $460 \mathrm{bp}$ & Townsend et al. [9] \\
\hline hyaD-hyaC & $\begin{array}{l}\text { CAPA Fwd } \\
\text { CAPA Rev }\end{array}$ & $\begin{array}{l}\text { TGCCAAAATCGCAGTCAG } \\
\text { TTGCCATCATTGTCAGTG }\end{array}$ & 1044 bp & Townsend et al. [10] \\
\hline$b c b D$ & $\begin{array}{l}\text { CAPB Fwd } \\
\text { CAPB Rev }\end{array}$ & $\begin{array}{l}\text { CATTIATCCAAGCTCCACC } \\
\text { GCCCGAGAGTTCAATCC }\end{array}$ & $760 \mathrm{bp}$ & Townsend et al. [10] \\
\hline$d c b F$ & $\begin{array}{l}\text { CAPD Fwd } \\
\text { CAPD Rev }\end{array}$ & $\begin{array}{l}\text { TTACAAAAGAAAGACTAGGAGCCC } \\
\text { CATCTACCCACTCAACCATATCAG }\end{array}$ & $657 \mathrm{bp}$ & Townsend et al. [10] \\
\hline toxA & $\begin{array}{l}\text { Forward } \\
\text { Reverse }\end{array}$ & $\begin{array}{l}\text { TCT TAG ATG AGC GAC AAG G } \\
\text { GAA TGC CAC ACC TCT ATA G }\end{array}$ & 846 bp & Shayegh et al. [11] \\
\hline$h g b B$ & $\begin{array}{l}\text { Forward } \\
\text { Reverse }\end{array}$ & $\begin{array}{l}\text { TCT TTG AGT ACG GCT TGA C } \\
\text { CTT ACG TCA GTA ACA CTC G }\end{array}$ & $540 \mathrm{bp}$ & Shayegh et al. [11] \\
\hline tbpA & $\begin{array}{l}\text { Forward } \\
\text { Reverse }\end{array}$ & $\begin{array}{l}\text { TGG TTG GAA ACG GTA AAG C } \\
\text { TAA CGT GTA CGG AAA AGC C }\end{array}$ & $728 \mathrm{bp}$ & Shayegh et al. [11] \\
\hline pfhA & $\begin{array}{l}\text { Forward } \\
\text { Reverse }\end{array}$ & $\begin{array}{l}\text { AGC TGA TCA AGT GGT GAA C } \\
\text { TGG TAC ATT GGT GAA TGC TG }\end{array}$ & $275 \mathrm{bp}$ & Shayegh et al. [11] \\
\hline nanB & $\begin{array}{l}\text { Forward } \\
\text { Reverse }\end{array}$ & $\begin{array}{l}\text { CAT TGC ACC TAA CAC CTC T } \\
\text { GGA CAC TGA TTG CCC TGA A }\end{array}$ & 555 bp & Tang et al. [12]; Ewer et al. [7] \\
\hline Oma87 & $\begin{array}{l}\text { Forward } \\
\text { Reverse }\end{array}$ & $\begin{array}{l}\text { GGC AGC GAG CAA CAG ATA ACG } \\
\text { TGT TCG TCA AAT GTC GGG TGA }\end{array}$ & 838 bp & Tang et al. [12]; Ewer et al. [7] \\
\hline ompH & $\begin{array}{l}\text { Forward } \\
\text { Reverse }\end{array}$ & $\begin{array}{l}\text { GCG TIT CAT TCA AAG CAT CTC } \\
\text { ATG ACC GCG TAA CGA CTT TC }\end{array}$ & $1000 \mathrm{bp}$ & Luo et al. [13] \\
\hline
\end{tabular}

P. multocida=Pasteurella multocida 
Available at www.veterinaryworld.org/Vol.11/March-2018/15.pdf

Table-2: Thermal cycling condition for the detection of virulence-associated genes of $P$. multocida.

\begin{tabular}{|c|c|c|c|c|c|c|c|}
\hline \multirow[t]{2}{*}{ PCR steps } & \multicolumn{7}{|c|}{ Gene } \\
\hline & $\operatorname{tox} A$ & $t b p A$ & $h g b B$ & pfhA & ompH & oma87 & nanB \\
\hline Initial & $95^{\circ} \mathrm{C}$ & $95^{\circ} \mathrm{C}$ & $95^{\circ} \mathrm{C}$ & $95^{\circ} \mathrm{C}$ & $94^{\circ} \mathrm{C}$ & $94^{\circ} \mathrm{C}$ & $94^{\circ} \mathrm{C}$ \\
\hline denaturation & $5 \min$ & $5 \min$ & $5 \min$ & $5 \min$ & $3 \mathrm{~min}$ & $3 \mathrm{~min}$ & $3 \mathrm{~min}$ \\
\hline \multirow[t]{2}{*}{ Denaturation } & $94^{\circ} \mathrm{C}$ & $94^{\circ} \mathrm{C}$ & $94^{\circ} \mathrm{C}$ & $94^{\circ} \mathrm{C}$ & $94^{\circ} \mathrm{C}$ & $94^{\circ} \mathrm{C}$ & $94^{\circ} \mathrm{C}$ \\
\hline & $45 \mathrm{~s}$ & $45 \mathrm{~s}$ & $45 \mathrm{~s}$ & $45 \mathrm{~s}$ & $30 \mathrm{~s}$ & $30 \mathrm{~s}$ & $30 \mathrm{~s}$ \\
\hline \multirow[t]{2}{*}{ Annealing } & $54^{\circ} \mathrm{C}$ & $54^{\circ} \mathrm{C}$ & $54^{\circ} \mathrm{C}$ & $54^{\circ} \mathrm{C}$ & $57^{\circ} \mathrm{C}$ & $55^{\circ} \mathrm{C}$ & $56^{\circ} \mathrm{C}$ \\
\hline & $50 \mathrm{~s}$ & $50 \mathrm{~s}$ & $50 \mathrm{~s}$ & $50 \mathrm{~s}$ & $30 \mathrm{~s}$ & $30 \mathrm{~s}$ & $30 \mathrm{~s}$ \\
\hline \multirow[t]{2}{*}{ Extension } & $72^{\circ} \mathrm{C}$ & $72^{\circ} \mathrm{C}$ & $72^{\circ} \mathrm{C}$ & $72^{\circ} \mathrm{C}$ & $72^{\circ} \mathrm{C}$ & $72^{\circ} \mathrm{C}$ & $72^{\circ} \mathrm{C}$ \\
\hline & $50 \mathrm{~s}$ & $50 \mathrm{~s}$ & $50 \mathrm{~s}$ & $50 \mathrm{~s}$ & $60 \mathrm{~s}$ & $60 \mathrm{~s}$ & $45 \mathrm{~s}$ \\
\hline Number of cycles & 35 & 35 & 35 & 35 & 25 & 25 & 30 \\
\hline Final extension & \multirow{2}{*}{\multicolumn{7}{|c|}{$72^{\circ} \mathrm{C} 10 \mathrm{~min}$}} \\
\hline Hold & & & & & & & \\
\hline References & $\begin{array}{l}\text { Shayegh } \\
\text { et al. [11] }\end{array}$ & $\begin{array}{l}\text { Shayegh } \\
\text { et al. [11] }\end{array}$ & $\begin{array}{l}\text { Shayegh } \\
\text { et al. [11] }\end{array}$ & Shayegh et al. [11] & Ewer et al. [7] & Ewer et al. [7] & Ewer et al. [7] \\
\hline
\end{tabular}

P. multocida $=$ Pasteurella multocida, $\mathrm{PCR}=$ Polymerase chain reaction

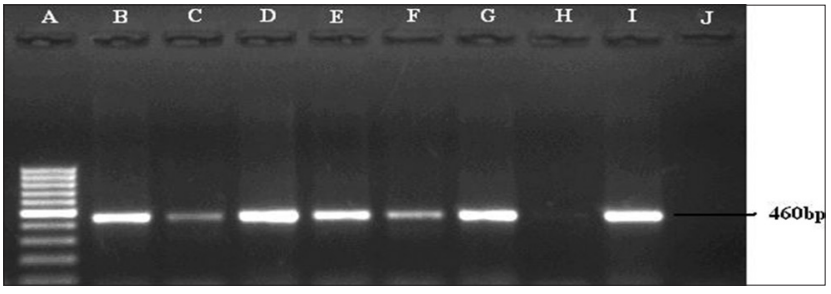

Figure-1: Pasteurella multocida species-specific polymerase chain reaction for the detection of KMT1 gene (460 bp) of $P$. multocida. Lane A: 100 bp DNA Ladder. Lane $\mathrm{B}$ to $\mathrm{H}$ : Samples positive for $\mathrm{kmt}$ gene. Lane J: Negative control.

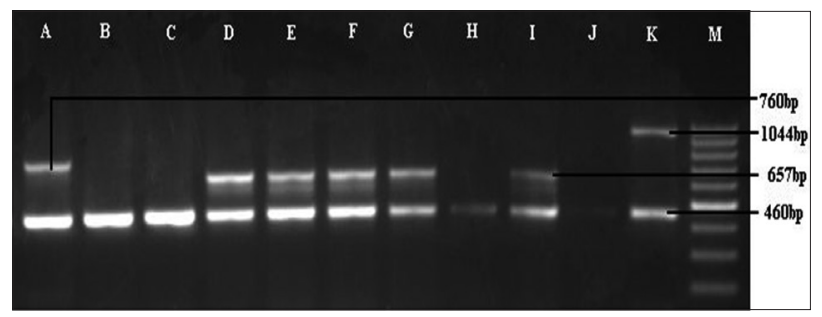

Figure-2: Multiplex-polymerase chain reaction for capsular typing of Pasteurella multocida. Lane A: Reference strain $\left(P_{52}\right)$. Lane $D, E, F, G$, and I: Sample positive for cap $D$. Lane K: Sample positive for cap A. Lane M: 100 bp DNA Ladder.

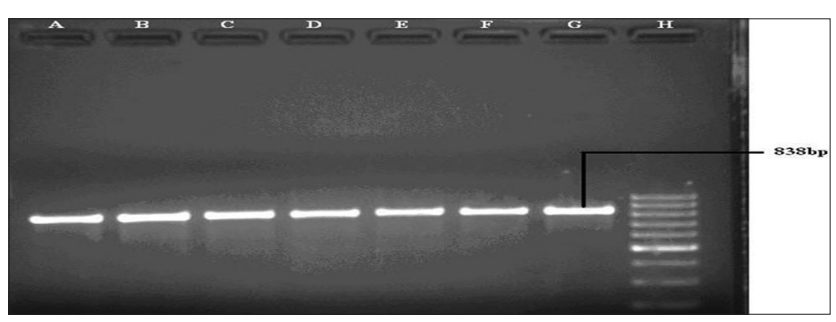

Figure-3: Polymerase chain reaction for the detection of oma87gene (838 bp) of Pasteurella multocida. Lane A to G: Samples positive for oma87 gene. Lane H: 100bp DNA Ladder.

and $1077 \mathrm{bp}$, respectively (Figures-3 and 4). The hemoglobin binding gene ( $h g b B$, Figure-5) was found in four $(57.14 \%)$ isolates of serotype D only, while tbpA (Figure-6) gene was detected in four (21.42\%) serotype A isolates only.
On amplification of filamentous hemagglutinin gene ( $p f h A)$, of the 21 isolates, six exhibited the presence of the same by yielding an expected amplicon size of $275 \mathrm{bp}$ (Figure-7), of which 5 isolates belong to serotype A (35.71\%) and 1 to serotype D (14.28\%). The sialidase coding gene (nanB) was detected only in $2(28.57 \%)$ isolates of serotype D (Figure-8).

Toxigenic gene (toxA) was detected in five isolates, of which three were serotype A $(21.42 \%)$, while 2 isolates of serotype D (28.57\%). toxA gene was absent in the reference strain $\mathrm{P}_{52}$ strain (Figure-9).

\section{Discussion}

The present paper describes as the first report of virulence gene profiles of porcine $P$. multocida from Assam, India. Pasteurellosis is a common disease of pigs worldwide with specific serotype and pathotype associated with the respiratory disease [16-18]. However, the distribution pattern of the serotypes and pathotypes can vary considerably from region to region and over time in a given region $[12,19]$. The present study results in the detection of more percentage of serotype A than serotype $\mathrm{D}$. The isolates used in the present study were mainly from cases of the respiratory syndrome. A higher percentage of serotype A than serotype D in P. multocida isolates from indigenous pigs in central Kalorey et al. [20] and Northeast India $[19,21]$ have been reported.

Variable distribution of the virulence genes was observed among the serotypes of $P$. multocida during the present study (Table-3). However, no correlation could be established with respect to the presence of virulence gene and serotypes of the Wide spread. Widespread distribution of $h g b B$ gene among the porcine $P$. multocida strains and its regular detection in capD strains compared to capA strains of P. multocida was also reported $[7,22]$. On the contrary to the present detection of tbpA gene, Ewers et al. [7] could detect the gene exclusively in bovine, sheep, and buffalo isolates and not in P. multocida pig strains. The present observation of $18.18 \%$ positive strains of $P$. multocida isolates possessing the tbpA gene could 


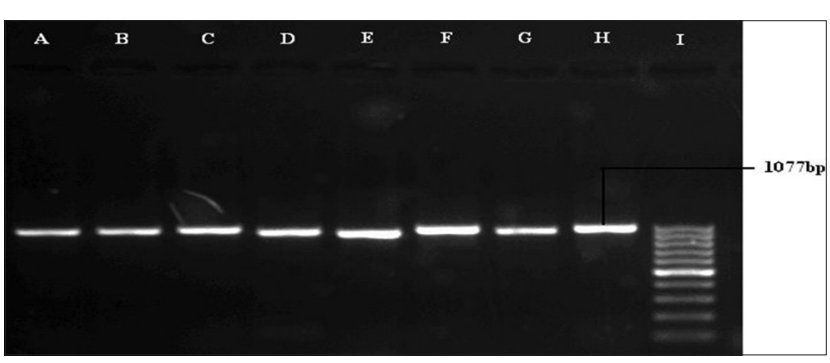

Figure-4: Polymerase chain reaction for the detection of $\mathrm{ompH}$ gene (1077 bp) of Pasteurella multocida. Lane A to $\mathrm{H}$ : Samples positive for ompH gene, Lane I: 100 bp DNA Ladder.

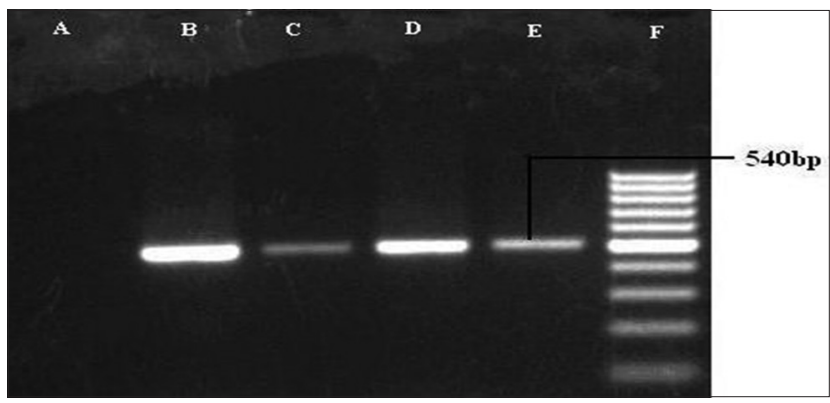

Figure-5: Polymerase chain reaction for the detection of hgbB gene (540 bp) of Pasteurella multocida. Lane A: Samples negative for $h g b B$ gene. Lane B, C, D, and $\mathrm{E}$ : Samples positive for $h g b B$ gene. Lane F: 100 bp DNA Ladder.

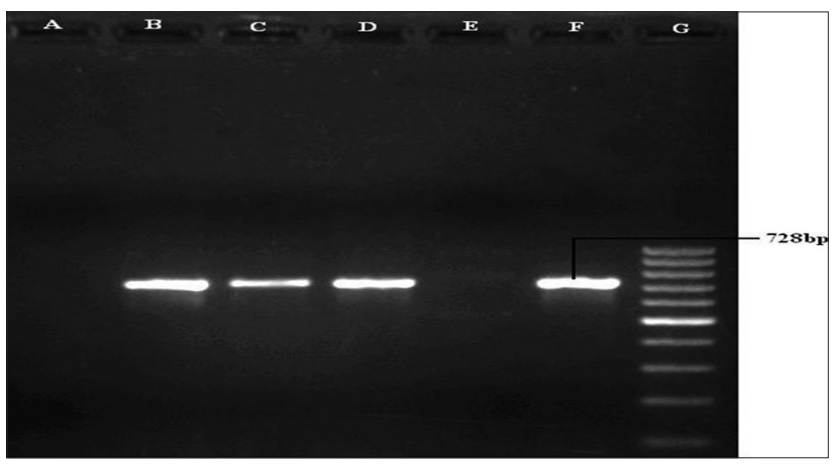

Figure-6: Polymerase chain reaction for the detection of tbpA gene (728 bp) of Pasteurella multocida. Lane B, C, $D$, and F: Samples positive for tbpA gene. Lane $A$ and $E$ : Samples negative for tbpA gene. Lane G: 100 bp DNA Ladder.

be probably due to interspecies transmission of $t b p A$ gene-positive $P$. multocida, as also suggested by Kumar et al. [23]. However, further study needs to be conducted before giving conclusive remark on interspecies transmission.

The present finding of low percent positivity of $p f h A$ gene in strains of serogroup D compared with serogroup A also supports the observations of association of filamentous hemagglutinin gene $p f h A$ with serogroups $\mathrm{A}, \mathrm{B}, \mathrm{E}$, and $\mathrm{F}[7,12,22]$.

The occurrence of OMP gene in porcine strains of P. multocida and its equal distribution among capsular serogroups (type A, type D, and other serotypes) was also reported [7,12,22]. P. multocida OMPs have been identified as potent immunogens [24] as reported by Rajkhowa et al. [25] and play a significant role in the pathogenesis

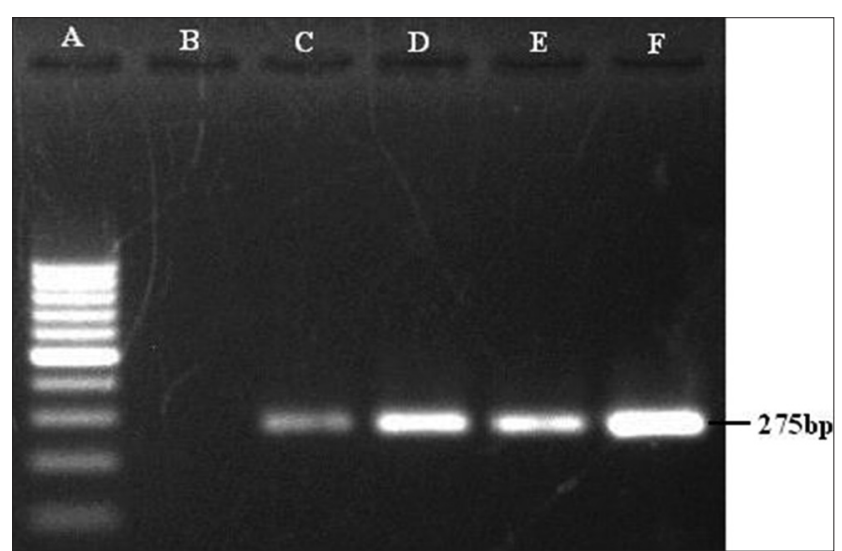

Figure-7: Polymerase chain reaction for the detection of pfhA gene (275 bp) of Pasteurella multocida. Lane A: 100 bp DNA Ladder, Lane B: Samples negative for pfhA gene, Lane C to F: Samples positive for $p f h A$ gene.

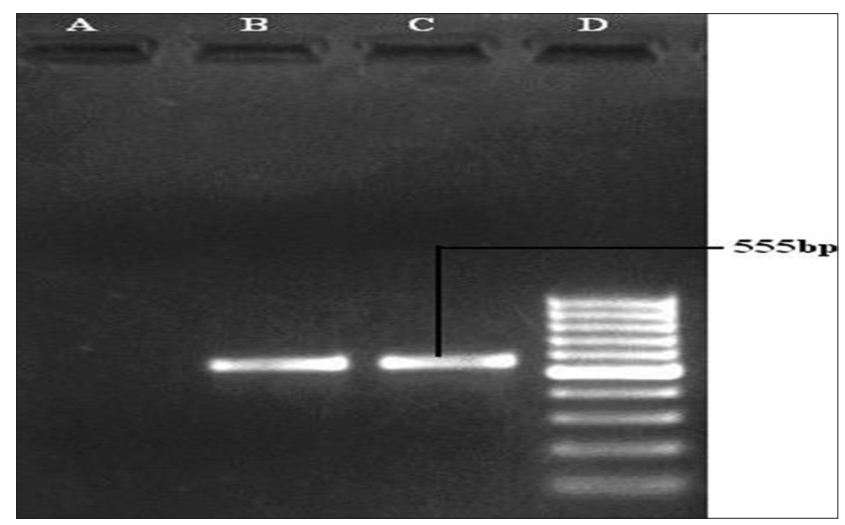

Figure-8: Polymerase chain reaction for the detection of nanB gene (555 bp) of Pasteurella multocida. Lane A: Samples negative for nanB gene. Lane B and C: Samples positive for nanB gene. Lane D: 100 bp DNA Ladder.

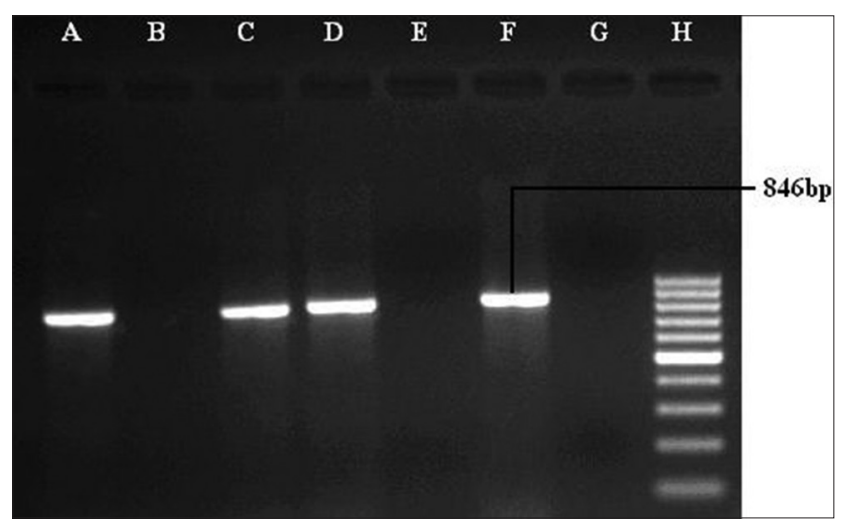

Figure-9: Polymerase chain reaction for the detection of toxA gene (846 bp) of Pasteurella multocida. Lane A, C, $\mathrm{D}$, and F: Samples positive for toxA gene. Lane $\mathrm{B}, \mathrm{E}$, and $\mathrm{G}$ : Samples negative for toxA gene. Lane $\mathrm{H}$ : 100 bp DNA Ladder.

of pasteurellosis [26]. Hazarika et al. [27] also reported that the sonicated and bacterin vaccines prepared from pig strains of $P$. multocida conferred $100 \%$ protection against homologous as well as heterologous strains compared to 66.66 and $86.66 \%$ protection with vaccine prepared from reference strain $\left(\mathrm{P}_{52}\right)$. From the present study, it can be opined that the OMP gene has a great 
Table-3: Virulence-associated gene detection in different serotypes of swine Pasteurella multocida by PCR and their pathogenicity in mice.

\begin{tabular}{|c|c|c|c|c|c|c|c|c|c|c|}
\hline \multirow[t]{2}{*}{ S. No. } & \multirow[t]{2}{*}{ Isolate No. } & \multirow[t]{2}{*}{ Serotype } & \multicolumn{7}{|c|}{ Virulence genes } & \multirow[t]{2}{*}{ Pathogenicity } \\
\hline & & & $\operatorname{tox} A$ & $\operatorname{nan} B$ & tbpA & pfhA & $h g b B$ & oma87 & ompH & \\
\hline 1 & P2 & A & - & & & & & + & + & (83.33) \\
\hline 2 & P3 & A & & & & & & + & + & \\
\hline 3 & P4 & A & & & & & & + & + & $(66.66)$ \\
\hline 4 & P6 & A & & & & & & + & + & $(83.33)$ \\
\hline 5 & P16 & $A$ & & & & & & + & + & \\
\hline 6 & P19 & $A$ & & & & & & + & + & \\
\hline 7 & P20 & $A$ & & & & & & + & + & \\
\hline 8 & $\mathrm{P} 22$ & $A$ & & & & & & + & + & $(50)$ \\
\hline 9 & P5 & $A$ & & & & + & & + & + & $(83.33)$ \\
\hline 10 & P7 & A & & & & + & & + & + & \\
\hline 11 & P13 & A & & & & + & & + & + & \\
\hline 12 & P14 & A & + & & + & + & & + & + & $(100)$ \\
\hline 13 & P18 & A & + & & + & + & & + & + & $(83.33)$ \\
\hline 14 & P10 & A & + & & + & & & + & + & $(100)$ \\
\hline \multicolumn{2}{|c|}{ Sub total } & 14 & $3(21.42)$ & 0 & $3(21.42)$ & $5(35.71)$ & 0 & $14(100)$ & $14(100)$ & $8(57.14)$ \\
\hline 15 & P1 & D & & & & & & + & + & \\
\hline 16 & P9 & D & & & & & & + & + & \\
\hline 17 & P15 & D & + & + & & & + & + & + & $(100)$ \\
\hline 18 & P17 & D & & & & & + & + & + & \\
\hline 19 & $\mathrm{P} 21$ & D & & & & & + & + & + & $(50)$ \\
\hline 20 & P8 & D & & + & & & & + & + & $(33.33)$ \\
\hline 21 & P11 & $\mathrm{D}$ & + & & & + & + & + & + & $(100)$ \\
\hline \multicolumn{2}{|c|}{ Sub total } & 7 & $2(28.57)$ & $2(28.57)$ & 0 & $1(14.28)$ & $4(57.14)$ & $7(100)$ & $7(100)$ & $4(57.14)$ \\
\hline 22 & P12 & $B\left(P_{52}\right)$ & 0 & 0 & 1 & 1 & 0 & 1 & 1 & $(100)$ \\
\hline \multicolumn{2}{|c|}{ Grand total } & 22 & $5(22.72)$ & $2(9.09)$ & $4(18.18)$ & $7(31.81)$ & $4(18.18)$ & $22(100)$ & $22(100)$ & $13(59.09)$ \\
\hline
\end{tabular}

$\mathrm{PCR}=$ Polymerase chain reaction

role in pathogenesis of P. multocida infection irrespective of the serotypes. Considering the immunogenic potential of the OMPs, both the genes can be explored in the development of a suitable vaccine against swine pasteurellosis. However, before giving any conclusive remarks on distribution and its applicability as vaccine candidate, a detailed study will be required involving a large number of isolates recovered from pigs of different parts of the Northeastern region.

The $13(59.09 \%)$ pathogenic isolates were found to possess different combinations of virulence genes. Pathogenic serotype A isolates with different virulence gene combinations produce $83.33-100 \%$ mortality in inoculated mice when compared to isolates with the presence of only OMP genes (50-83.33\%). Similarly, serotype D isolates with different virulence gene combinations produce $33.33-100 \%$ mortality in inoculated mice. No reports could be traced out from the available literature with respect to the correlation between presence virulence gene in the $P$. multocida isolates and their pathogenicity in mice. However, it can be opined from the present observation that OMP alone is not responsible for pathogenesis of the disease and association of other VGAs with OMP gene might play a key role in pathogenesis. The present study indicates that toxA gene plays an important role in pathogenesis of $P$. multocida in pigs, which is supported by the findings of many workers [28-30]. Among the other virulence genes, $\operatorname{tbp} A$ gene was found to be closely associated with pathogenesis of the P. multocida. Contrary to the present findings, Ewers et al. [7] reported the presence of tbpA gene only in bovine strains of P. multocida and could not detect in porcine strains. Although they observed a significant association between $p f h A$ and tox $A$ with clinically diseased swine, toxA alone was found to be associated with the disease status independently. A perusal of the literature reveals that there is no report on the detection of $t b p A$ gene from porcine strains, the detection of the gene in highly pathogenic porcine isolate is an important finding, and its role in pathogenesis needs further investigation. During the present study, some of the P. multocida isolates could not produce mortality in mice following inoculation with $P$. multocida isolate having virulence gene, either alone or in combination. This might be due to repeated subculturing of the isolates in laboratory media that result in the suppression of gene function or due to gene mutation, resulting in non-expression of the genes in vivo $[31,32]$. Detection of a high proportion of toxigenic capsular type A P. multocida from pigs was also reported by other workers [11,20,30,33]. Detection of toxin gene in both the type A and D isolates of $P$. multocida of the region in the present study indicates its important role in the disease pathogenesis mechanism.

\section{Conclusion}

From the present study, it can be concluded that tox $A$ gene is an important marker gene for defining the pathogenic potential of $P$. multocida strains in swine. However, other virulence genes are also found to be distributed well among pathogenic strains of $P$. multocida. Among the other virulence genes, $t b p A$ gene 
was found to be closely associated with the pathogenesis of the P. multocida. The association of the gene in disease producing mechanism needs further evaluation.

\section{Authors' Contributions}

This study was a part of LBD's research work during his $\mathrm{PhD}$ program. LBD carried out the experiment. SKD, RKS, and DPB designed the experiment. SKD, RKS, DPB, SM, and RAH provided necessary guidelines. DPB drafted the final manuscript. All authors have read and approved the final manuscript.

\section{Acknowledgments}

The authors would like to thank the Indian Council of Agricultural Research (ICAR) for providing financial help to carry out the research under Network Project on Hemorrhagic Septicemia (NWP on HS). Grant no. F.No 1(23)/02-IA-I dated $9^{\text {th }}$ Feb, 2004.

\section{Competing Interests}

The authors also declare that there are no conflicts.

\section{References}

1. Hatfaludi, T., Al-Hasani, K., Boyce, J.D. and Adler, B. (2010) Outer membrane proteins of Pasteurella multocida. Vet. Microbiol., 144: 1-17.

2. Sarangi, L.N., Priyadarshini, A., Kumar, S., Thomas, P., Gupta, S.K., Nagaleekar, V.K. and Singh, V.P. (2014) Virulence genotyping of Pasteurella multocida isolated from multiple hosts from India. Sci. World J., 2014: 1-10.

3. Harper, M., Boyce, J.D. and Adler, B. (2006). Pasteurella multocida pathogenesis: 125 years after Pasteur. FEMS Microbiol. Lett., 265: 1-10.

4. Ujvári, B., Szeredi, L., Pertl, L., Tóth, G., Erdélyi, K.K., Jánosi, S., Molnár, T. and Magyar, T. (2015) First detection of Pasteurella multocida Type B: 2 in Hungary associated with systemic pasteurellosis in backyard pigs. Acta Vet. Hung. 63: 141-156.

5. Hunt, M.L., Adler, B. and Townsend, K.M. (2000) The molecular biology of Pasteurella multocida. Vet. Microbiol., 72: 3-25.

6. Hunt, M.L., Boucher, D.J., Boyce, J.D. and Adler, B. (2001). In vivo-expressed genes of Pasteurella multocida. Infect. Immun., 69: 3004-3012.

7. Ewers, C., Lu"bke-Becker, A., Bethe, A., Kiebling, S., Filter, M. and Wieler, L.H. (2006) Virulence genotype of Pasteurella multocida strains isolated from different hosts with various disease status. Vet. Microbiol., 114: 304-317.

8. Ewers, C., Lu"bke-Becker, A. and Wieler, L.H. (2004) Pasteurella: Insights into the virulence determinants of a heterogenous bacterium. Berl. Munch. Tierarztl. Wochenschr., 9-10: 367-386.

9. Townsend, K.M., Frost, A.J., Lee, C.W., Papadimitriou, J.M. and Dawkins, H.J. (1998) Development of PCR assays for species- and type-specific identification of Pasteurella multocida isolates. J. Clin. Microbiol., 36: 1096-1100.

10. Townsend, K.M., Boyce, J.D., Chung, J.Y.A., Frost, J. and Adler, B. (2001) Genetic organization of Pasteurella multocida cap loci and development of a multiplex capsular PCR typing system. J. Clin. Microbiol., 39: 924-929.

11. Shayegh, J., Atashpaz, S. and Hejazi, M.S. (2008). Virulence genes profile and typing of ovine Pasteurella multocida. Asian J. Anim. Vet. Adv., 3: 206-213.

12. Tang, X., Zhao, Z., Hu, J., Wu, B., Cai, X., He, Q. and Chen, H. (2009). Isolation, antimicrobial resistance, and virulence genes of Pasteurella multocida strains from Swine in China. J. Clin. Microbiol., 47: 951-958.

13. Luo, Y., Glisson, J.R., Jackwood, M.W., Hancock, R.E., Bains, M., Cheng, I.H. and Wang, C. (1997). Cloning and characterization of the major outer membrane protein gene (ompH) of Pasteurella multocida X-73. J. Bacteriol., 179: 7856-7864.

14. Curtis, P.E. (1985) Pasteurella multocida. In: Collins, C.H., Grange, J.M., editors. Isolation and Identification of Microorganisms of Medical and Veterinary Importance. Academic Press, London.

15. Wijewardana, T.G. (1992) Haemorrhagic septicaemia. Diagnostic and Vaccine Production Procedures. FAO Regional Reference Laboratory (Asian Region). Veterinary Research Institute, Department of Animal Production \& Health, Paradeniya, Sri Lanka.

16. Pors, S.E., Hansen, M.S., Bisgaard, M., Jensen, H.E. and Iburg, T.M. (2013) Immuno histochemical study of porcine lung lesions associated with Pasteurella multocida. Vet. J., 197: 483-488.

17. Tigga, M., Ghosh, R.C., Malik, P., Choudhary, B.K., Tigga, P. and Nagar, D.K. (2014) Isolation, characterization, antibiogram and pathology of isolated from pigs. Vet. World, 7: 363-368.

18. Choudhary, M., Ghosh, R.C., Malik, P., Choudhary, B.K. and Nety, S. (2017) Pathological changes associated with natural outbreak of swine pasteurellosis. J. Pure Appl. Microbiol., 11: 237-240.

19. Varte, Z., Dutta, T.K., Roychoudhury, P., Begum, J. and Chandra, R. (2014) Isolation, identification, characterization and antibiogram of Pasteurella multocida isolated from pigs in Mizoram with special reference to progressive atrophic rhinitis. Vet. World, 7: 95-99.

20. Kalorey, D.R., Yuvaraj, S., Vanjari, S.S., Gunjal, P.S., Dhanawade, N.B., Barbuddhe, S.B. and Bhandarkar, A.G. (2008) PCR analysis of Pasteurella multocida isolates from an outbreak of pasteurellosis in Indian pigs. J. Comp. Immunol. Microbiol. Infect. Dis., 31: 459-465.

21. George, S., Rajbongshi, G., Deuri, S., Khatoon, A. and Barman, N.N. (2012) Simultaneous occurrence of pneumonic pasteurellosis and swine fever in an organised pig farm in Assam. North East Vet., 12: 5-8.

22. Bethe, A., Wieler, L.H., Selbitz Hans, J. and Ewers, C. (2009) Genetic diversity of porcine Pasteurella multocida strains from the respiratory tract of healthy and diseased swine. Vet. Microbiol., 139: 97-105.

23. Kumar, H., Mahajan, V., Sharma, S., Alka., Singh, R., Arora, A.K, Banga, H.S, Verma, S., Kaur, K., Kaur, P. and Meenakshi Sandhu, K.S. (2007) Concurrent pasteurellosis and classical swine fever in Indian pigs. J. Swine Health. Prod., 15: 279-283.

24. Singh, R., Tewari, K., Packiriswamy, N., Marla, S. and Rao, V.D.P. (2011) Molecular characterization and computational analysis of the major outer membrane protein (omph) gene of Pasteurella multocida p52. Vet. Arhiv., 81: 211-222.

25. Rajkhowa, S., Shakuntala, I., Pegu, S.R., Das, R.K. and Das, A. (2012) Detection of Pasteurella multocida isolates from local pigs of India by polymerase chain reaction and their antibiogram. Trop. Anim. Health Prod., 44: 1497-1503.

26. Srivastava, S.K. (1998) Outer membrane protein of Pasteurella multocida serotype B: 2 are immunogenic and antiphagocytic. Ind. J. Exp. Biol., 36: 530-532.

27. Hazarika, M.P., Barman, N.N., George, S. and Sharma, R.K. (2011) Characterization of Pasteurella multocida isolated from pneumonic pigs of Assam. Indian J. Anim. Res., 44: 265-269.

28. Jong, M.F. (2006). In: Straw, B.E., Zimmerman, J.J., d'Allaire, S., Taylor, D.J., editors. Diseases of Swine. $9^{\text {th }}$ ed. Iowa State University Press, Ames, Iowa, USA. p577-602.

29. Martineau, G.P., Broes, A. and de Jong, M.F. (1982) Experimental reproduction of atrophic rhinitis with 
Pasteurella multocida on gnotobiotic and conventional piglets. Proc. Int. Pig Vet. Soc. Cong. (Subject Rhinitis). 6: 88 .

30. Rutter, J.M. and Rojas, X. (1982) Atrophic rhinitis in gnotobiotic piglets: Differences in the pathogenicity of Pasteurella multocida in combined infection with Bordetella bronchoseptica. Vet. Rec., 110: 531-535.

31. Borowski, S.M., Silva, S.C., Schrank, I. and Cardoso, M. (2001) Toxin detection in Pasteurella multocida strains isolated from swine lungs in the state of Rio Grande do Sul,
Brazil. Arq. Fac. Vet. UFRGS, 29: 79-85.

32. Stępniewska K. and Markowska-Daniel, I. (2013) Phenotypic and genotypic characterization of Pasteurella multocida strains isolated from pigs in Poland. Bull. Vet. Inst. Pulawy., 57: 29-3.

33. Cardoso, T.F., Laguna, G.J., Callejo, M., Vela, A.I., Carrasco, L., Fernandez, G.J.F., Maldonado, A. and Luque, I. (2013) Septicaemic pasteurellosis in free-range pigs associated with an unusual biovar 13 of Pasteurella multocida. Vet. Microbiol., 167: 690-694.

$* * * * * * * *$ 